\title{
ARBUSCULAR MYCORRHIZA AND PLANT SUCCESSION ON ZINC SMELTER SPOIL HEAP IN KATOWICE-WEENOWIEC
}

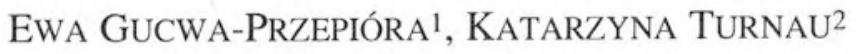 \\ 1Department of Plant Systematics, Silesian University \\ ul. Jagiellońska 28, 40-032 Katowice, Poland \\ e-mail: egucwa@us.edu.pl \\ 2Insitute of Botany, Jagiellonian University \\ ul. Lubicz 46, 31-512 Kraków, Poland \\ e-mail: ubturnau@cyf-kr.edu.pl
}

(Received: February 9, 2001. Accepted: April 2, 2001)

\begin{abstract}
Mycorrhizal status of plants colonising the zinc wastes in Katowice was surveyed. In total 69 vascular plant species (25 families) appearing on the investigated area have been noted. More than $60 \%$ of them were mycorrhizal. Non-mycorrhizal species, such as Cardaminopsis arenosa and Silene vulgaris dominated the early successional part of the zinc heap. Tussilago farfara was the only AM plant there, however, no arbuscules were developed at this stage. The number of AM species was increased on the 20 years old part of the zinc wastes and on the older 30-50 years old areas. AM plants constituted about $60 \%$ of the total number of species there. The frequency of particular AM species was the highest on the oldest part of the investigated area. The usefulness of the results for restoration practices was discussed.
\end{abstract}

KEY WORDS: arbuscular mycorrhiza, industrial wastes, heavy metals.

\section{INTRODUCTION}

Industrial wastes and strip-mines are a typical element of the Silesia region (South Poland). They cover over 3500 ha of land in the Katowice district and are often located close to large agglomerations. To overcome the problem of wind erosion, which creates a health hazard for local populations, the necessity to establish plant vegetation on the surface of the waste is an important goal. The substratum, however, is rather hostile for spontaneously appearing vegetation as it is often toxic to plant growth, low in mineral nutrient and lacking typical soil characteristics. The plant composition of the successional seres in this region is relatively well known (Rostański 1991, 1997a, b; Patrzałek and Rostański 1992; Tokarska-Guzik et al. 1991; Wika and Sendek 1993) documenting the dominance of wind dispersed, native, expansive species typical for anthropogenic environments (Faliński 1972; Rostański 1990). Due to the large area of the wastes the only possible remediation technique is onsite management, which would involve practices improving soil quality, introduction of properly selected plants and soil biota. In recent years substantial attention has been paid to mycorrhizal fungi which could be potentially used in revegetation of damaged ecosystems (Haselwandter 1997). While ectomycorrhizal fungi have already been successfully used in such cases, arbuscular fungi (AMF) still await the practical application despite the fact that this kind of mycorrhiza is the most important in plants which are useful for fast revegetation of the area.
Although their contribution to increasing plant community production and structure, plant nutrition, soil structure development, diminishing water stress and increasing plant health status is well known, still the development of inoculation techniques, involving the selection of fungal strains adapted to toxic conditions under the given climatic and edaphic conditions is missing. The development of practices promoting growth and multiplication of AM fungi appearing spontaneously in such areas also requires the analysis of the mycorrhizal status of native plants colonising the wastes and the selection of those which would be the most effective in promoting fungal growth and stimulation. Although the mycorrhizal colonisation level can not serve as an indicator of the effectivity of the symbiosis, this parameter may be useful in monitoring the success of restoration or ecosystem stability (Lovera and Cuenca 1996). In addition, strongly colonised plant roots are one of the sources of the inoculum for other mycorrhizal plants, which will subsequently appear in the vicinity and thus contribute to the creation of more diverse vegetation system. Therefore, the aim of the present work was to study the mycorrhizal status of the plants spontaneously establishing during the successional stages of the revegetation of Katowice-Wełnowiec zinc wastes. This is considered as an important step in increasing the knowledge of mycorrhizal associations of this area and the start-point for further analysis of AM fungi diversity and selection of practically important fungal and plant species for restoration practices. 
TABLE 1. Chemical properties of the zinc smelter spoil heap substrate in Katowice.

\begin{tabular}{|c|c|c|c|c|}
\hline Part of heap & Below 20 years old & 20 years old & 30-40 years old & 50 years old \\
\hline $\mathrm{pH}$ & 6.53 & 7.75 & 7.88 & 8.06 \\
\hline $\mathrm{C}$ organic $|\%|$ & 9.92 & 8.73 & 6.24 & 3.14 \\
\hline $\mathrm{N} \mid \%]$ & 0.17 & 0.22 & 0.21 & 0.14 \\
\hline $\mathrm{P}_{2} \mathrm{O}_{5}$ Img $\cdot 100 \mathrm{~g} \cdot 1$ p.s.m. $]$ & 1.0 & 0.2 & 0.4 & 3.8 \\
\hline $\mathrm{K}_{2} \mathrm{O} \mid \mathrm{mg} \cdot 100 \mathrm{~g}-1$ p.s.m. $\mid$ & 4.4 & 7.75 & 6.3 & 9.5 \\
\hline \multicolumn{5}{|l|}{ Total metals $\left|\mu \mathrm{g} \cdot \mathrm{g}^{-1}\right|$} \\
\hline $\mathrm{Zn}$ & 17410 & 17286 & 12901 & 7260 \\
\hline $\mathrm{Pb}$ & 18666 & 17137 & 17996 & 11157 \\
\hline $\mathrm{Cd}$ & 353 & 856 & 7023 & 173 \\
\hline $\mathrm{Cu}$ & 1221 & 313 & 1549 & 1328 \\
\hline \multicolumn{5}{|c|}{$\mathrm{Ca}\left(\mathrm{NO}_{3}\right)_{2}$ extractable metals $\left|\mu \mathrm{g} \cdot \mathrm{g}^{-1}\right|$} \\
\hline $\mathrm{Zn}$ & 137.4 & 42.47 & 29.72 & 26.92 \\
\hline $\mathrm{Pb}$ & 4.3 & 1.45 & 2.5 & 1.45 \\
\hline $\mathrm{Cd}$ & 10.0 & 2.54 & 2.77 & 0.35 \\
\hline $\mathrm{Cu}$ & 0.46 & 0.33 & 0.33 & 0.6 \\
\hline
\end{tabular}

\section{MATERIALS AND METHODS}

\section{Sampling site}

The investigated zinc wastes which were studied in 1994 to 1997 are located in Wełnowiec, which is an industrial district of the city Katowice (Upper Silesia, southern Poland). The wastes occupy 25 ha (288-313 m above sea level). The slopes of the wastes were often very steep $\left(40-45^{\circ}\right)$ (Wojcierowska 1968). They are composed of floss from muffle furnaces, ash, waste materials from distillation and roasting furnaces and chamotte bricks. Presently, the area is abandoned.

Table 1 shows the physico-chemical soil characteristics of wastes of different age, reflecting the low content of organic matter, the low $\mathrm{P}$ and $\mathrm{N}$ content, and the high total heavy metal content.

\section{Substratum sampling and analysis}

Topsoil (0-15 cm depth) was sampled in May 1996. Five subsamples were collected at random points from each waste of different age. Sub-samples were then bulked, sieved and air dried for soil extraction. Total and extractable (in $2 \mathrm{~N} \mathrm{HNO}_{3}$ and 0.1 $\left.\mathrm{M} \mathrm{Ca}\left(\mathrm{NO}_{3}\right)_{2}\right)$ elements in soils were determined with atomic absorption spectrometry (Ostrowska et al. 1991; Weissenhorn et al. 1995), $\mathrm{N}$ with the Kjeldahl method, organic matter with the Tiurin method, and available $\mathrm{P}$ and $\mathrm{K}$ with the Egner-Rhiem method (Lityński and Jurkowska 1982).

\section{Plant sampling and preparation}

The identification of plant species was carried out during the first vegetative season (from May to October). The plant material was deposited in the herbarium of the Department of Plant Systematics of the Silesian University (KTU). Latin names of plant species follow Excursionsflora (Rothmaler 1994). The percentage of plant cover and type of spatial distribution was estimated according to the commonly used Braun-Blanquet method (Braun-Blanquet 1964). Root samples of at least five plants from each sere of the zinc smelter spoil heaps, differing in age, were collected monthly during vegetative seasons 19941997. The roots were stained according to modified Phillips and Hayman's method (1970). The roots were washed in distilled water, cleared in $7 \% \mathrm{KOH}$ at $60^{\circ} \mathrm{C}$ for 1 hour, rinsed in a few changes of water, acidified in $5 \%$ lactic acid at room temperature for 1-24 hours and stained in 0.05 trypan blue at $60^{\circ} \mathrm{C}$ for 0.5 hour. Stained roots were stored in lactoglycerol until they were used for slide preparation. Mycorrhizal colonisation and presence of AM structures (arbuscules, vesicles, coils and spores) were estimated according to the method described by Trouvelot et al. (1986).

\section{RESULTS}

\section{AM status of the youngest wastes (under 20 years old)}

The youngest zinc wastes were sparsely colonised by plants. Only ten species were noted there. The most common were non mycorrhizal Cardaminopsis arenosa and Festuca ovina (Table 2). Tussilago farfara, which was, however, much less common than the two mentioned species, was the only one where AMlike mycelia, coils and vesicles were found. No arbuscules were observed (Table 3 ).

TABLE 2. Non-mycorrhizal plant species from the zinc smelter spoil heap in Katowice

(parts of the heap are named as follows: 0 - up to 20 years old part, 1 -20 years old part, $2-30-40$ years old part, 3 - over 50 years old part).

\begin{tabular}{|c|c|c|c|c|c|}
\hline \multirow{2}{*}{ Family } & \multirow{2}{*}{ Species } & \multicolumn{4}{|c|}{ Part of heap } \\
\hline & & 0 & 1 & 2 & 3 \\
\hline Asteraceae & $\begin{array}{l}\text { Crepis biennis } \\
\text { Erigeron acer } \\
\text { Eupatorium cannabinum }\end{array}$ & & $\begin{array}{l}X \\
X \\
\end{array}$ & $\begin{array}{l}X \\
X \\
X\end{array}$ & $\begin{array}{l}X \\
X \\
X\end{array}$ \\
\hline Boraginaceae & Echium vulgare & & $\mathrm{X}$ & $\mathrm{X}$ & $\mathrm{X}$ \\
\hline Brassicaceae & Cardaminopsis arenosa & $\mathrm{X}$ & $\mathrm{X}$ & $\mathrm{X}$ & \\
\hline Caryophyllaceae & Silene vulgaris & $\mathrm{X}$ & $\mathrm{X}$ & $\mathrm{X}$ & $\mathrm{X}$ \\
\hline Chenopodiaceae & $\begin{array}{l}\text { Atriplex patula } \\
\text { Chenopodium album }\end{array}$ & & & $\mathrm{X}$ & $\mathrm{X}$ \\
\hline Cyperaceae & $\begin{array}{l}\text { Carex hinta } \\
\text { Carex spicata }\end{array}$ & & & $\mathrm{X}$ & $\mathrm{X}$ \\
\hline Poaceae & $\begin{array}{l}\text { Agropyron repens } \\
\text { Calamagrostis epigeios } \\
\text { Deschampsia caespitosa } \\
\text { Poa pratensis }\end{array}$ & $\mathrm{X}$ & $\begin{array}{l}X \\
X\end{array}$ & $\begin{array}{l}X \\
X\end{array}$ & $\begin{array}{l}X \\
X\end{array}$ \\
\hline Polygonaceae & $\begin{array}{l}\text { Polygonum aviculare } \\
\text { Reynoutria japonica } \\
\text { Rumex acetosa }\end{array}$ & $\mathrm{X}$ & $X$ & $\begin{array}{l}X \\
X\end{array}$ & $\begin{array}{l}X \\
X\end{array}$ \\
\hline Resedaceae & Reseda lutea & $\mathrm{X}$ & $\mathrm{X}$ & $\mathrm{X}$ & $\mathrm{X}$ \\
\hline Scrophulariaceae & Verbascum densiflorum & & & $\mathrm{X}$ & $\mathrm{X}$ \\
\hline Solanaceae & Solanum dulcamara & & $\mathrm{X}$ & & \\
\hline Unicaceae & Urtica dioica & & & & $\mathrm{X}$ \\
\hline Valerianaceae & Valeriana officinalis & & & $\mathrm{X}$ & \\
\hline
\end{tabular}


TABLE 3. AM presence and structures of plants from different parts of the wastes in Katowice (parts of the heap are named as follows: 0 - up to 20 years old part, 1 - 20 years old part, 2 - 30-40 years old part, 3 - over 50 years old part).

\begin{tabular}{|c|c|c|c|c|c|c|c|c|c|}
\hline \multirow{2}{*}{$\begin{array}{l}\text { Alphabetical list } \\
\text { of plant species }\end{array}$} & \multicolumn{4}{|c|}{ Abundance and type of spatial distribution } & \multirow{2}{*}{ AM presence } & \multicolumn{4}{|c|}{ AM structures } \\
\hline & 0 & 1 & 2 & 3 & & A & $\mathrm{C}$ & V & $\mathrm{S}$ \\
\hline Achillea millefolium & & 2.2 & & +.1 & + & + & + & + & - \\
\hline Agrostis capillaris & & 1.2 & & & $+1-$ & $\cdot$ & - & - & - \\
\hline Agrostis stolonifera & & & & 2.2 & $+1-$ & + & - & + & - \\
\hline Anhenatherum elatius & 1.2 & +.2 & & 1.2 & $+1-$ & + & $+1-$ & + & - \\
\hline Antemisia vulgaris & & & & 2.2 & + & + & + & + & - \\
\hline Campanula trachelium & & & r.1 & & + & - & + & + & + \\
\hline Centaurea jacea & & r. 1 & & & + & + & - & + & - \\
\hline Chenopodium rubrum & & & & +.2 & $+1-$ & - & + & + & \\
\hline Cirsium arvense & & & +.1 & r.1 & $+1-$ & + & +1 & $+1-$ & $+1-$ \\
\hline Cirsium vulgare & & & r. 1 & +.1 & + & + & + & + & - \\
\hline Convolvulus arvensis & & & +.1 & +.1 & $+1-$ & $+1-$ & $+1-$ & $+1-$ & - \\
\hline Daucus carota & & 1.1 & +.1 & 1.1 & $+1-$ & + & $+1-$ & + & - \\
\hline Deschampsia caespitosa & & +.2 & & & + & + & - & + & - \\
\hline Epilobium angustifolium & & & +.1 & & + & + & - & + & + \\
\hline Epilobium dodonaei & & & +.1 & & + & - & + & + & - \\
\hline Erigeron acer & & & +.1 & 2.2 & $+1-$ & + & - & + & - \\
\hline Euphorbia cyparissias & & 2.3 & & & + & + & - & + & - \\
\hline Festuca ovina & & 3.3 & 2.2 & 1.2 & $+1-$ & + & - & + & - \\
\hline Hieracium lachenalii & 2.3 & & +.1 & & + & + & + & + & - \\
\hline Hieracium murorum & & 1.1 & & & + & + & - & + & - \\
\hline Hieracium piloselloides & & & & 1.1 & + & + & - & + & - \\
\hline Holcus lanatus & & & +.2 & & + & + & + & + & - \\
\hline Leontodon autumnalis & & 2.2 & & & + & + & - & + & - \\
\hline Leontodon hispidus & & & +.1 & & + & + & - & + & - \\
\hline Linaria vulgaris & & 2.2 & & & + & + & $+/-$ & + & $+1-$ \\
\hline Linum cathanticum & & r. 1 & & & + & - & + & - & \\
\hline Medicago lupulina & & & & +.1 & + & + & + & + & - \\
\hline Melandrium album & & & 1.2 & 1.2 & $+1-$ & + & - & + & - \\
\hline Melilotus alba & & & +.1 & & + & + & - & + & + \\
\hline Myricaria germanica & & & 2.1 & & $+1-$ & + & - & + & + \\
\hline Oenothera biennis & & & r. 1 & & + & + & $+1-$ & + & - \\
\hline Plantago lanceolata & & 1.2 & 2.2 & 2.2 & $+1-$ & + & + & + & $+/-$ \\
\hline Populus tremula & & r. 1 & +.1 & 1.1 & $+1-$ & + & $+1-$ & + & $\cdot \quad-$ \\
\hline Reynoutria sachalinensis & & & & 1.3 & + & + & - & + & - \\
\hline Scrophularia nodosa & & +.1 & +.1 & & + & + & + & + & - \\
\hline Solidago gigantea & & 1.2 & 1.2 & 2.3 & + & + & $+1-$ & + & - \\
\hline Solidago virgaurea & & +.1 & & & + & + & + & + & - \\
\hline Sonchus avensis & & r. 1 & & & + & + & + & + & + \\
\hline Taraxacum officinale & & 1.1 & +.1 & 1.1 & + & + & $+/-$ & + & - \\
\hline Trifolium repens & & & 1.3 & & + & + & $+/$ & + & - \\
\hline Tripleurospermum inodorum & & & & +.2 & + & + & - & - & - \\
\hline Tussilago farfara & & 2.2 & +.2 & +.2 & $+1-$ & $+1-$ & $+1-$ & + & - \\
\hline Verbascum densiflorum & +.2 & & $\mathrm{r} .1$ & r.1 & + & + & $+/$ & + & - \\
\hline Vicia cracca & & & +.1 & +.1 & $+1-$ & + & +1 & + & - \\
\hline Viola tricolor & & r.1 & & +.1 & + & + & + & + & - \\
\hline
\end{tabular}

Abbreviations:

$\mathrm{AM}$ - arbuscular mycorrhiza; $\mathrm{A}$ - arbuscules; C - coils; V - vesicles; $\mathrm{S}$ - spores.

Each species' appearance is described by its abundance and type of spatial distribution in the patch according to the following rules: abundance: $\mathrm{r}-1-3$ individuals: +- the species covers up to $1 \%$ of the area; 1 - the species covers up to $5 \% ; 2$ - the species covers $5 \%$ to $25 \% ; 3-$ the species covers $25 \%$ to $50 \% ; 4-$ the species covers $50 \%$ to $75 \%$; the species covers $75 \%$ to $100 \%$; type of spatial distribution: 1 - single individuals, distributed randomly; $2-$ small groups of individuals (rosettes and small tufts); 3 - bigger groups of individuals (tufts, small patches); 4 - big turfs, rug-like groups of individuals; 5 - corn-like pattern (very abundant occurrence).

\section{0 years-old wastes}

The vegetation developed on 20 years old wastes was much more abundant than on younger wastes. The relative cover of the ground reached $70 \%$. It was dominated by nonmycorrhizal plants such as Calamagrostis epigeios, Cardaminopsis arenosa and Reseda lutea (Table 2). The number of mycorrhizal plant species increased to $60 \%$; their population, however, was not abundant. The most common in this group were Plantago lanceolata and Tussilago farfara. Some plants were heavily colonised (Table 4). Arbuscules were observed in 58\% of the observed plant species. In about $50 \%$ of these cases arbuscules were accompanied by coils (Table 3). The most abundant arbuscule formation was found in Plantago lanceolata, Centaurea jacea, Daucus carota and Hieracium murorum (Table 4).

\section{0-40 years-old wastes}

The vegetation cover at this stage was still about $70 \%$ but it was characterised by the highest richness of plant species. Among trees and shrubs the most common were Betula pendula, Salix caprea and Myricaria germanica, while among herbs Cardaminopsis arenosa, Silene vulgaris and Festuca ovina were still the most abundant. Mycorrhizal plants constituted 58\% of 
TABLE 4. Mycorrhizal colonization (M\%) and arbuscules abundance (A\%) of plants on different parts on the heap.

(values listed are means \pm standard deviations; parts of the heap are named as follows: 0 - up to 20 years old part, $1-20$ years old part, 2 - 30-40 years old part, 3 - over 50 years old part).

\begin{tabular}{|c|c|c|}
\hline Species & M\% & $\mathrm{A} \%$ \\
\hline \multicolumn{3}{|l|}{ Part 0} \\
\hline Tussilago farfara & $0.7 \pm 1.7$ & 0.0 \\
\hline \multicolumn{3}{|l|}{ Part 1} \\
\hline Achillea millefolium & $33.5 \pm 9.4$ & $23.9 \pm 2.5$ \\
\hline Amhenatherum elatius & $30.4 \pm 8.9$ & $8.0 \pm 3.8$ \\
\hline Centaurea jacea & $87.8 \pm 15.4$ & $68.2 \pm 16.2$ \\
\hline Daucus carota & $57.2 \pm 6.4$ & $56.0 \pm 4.9$ \\
\hline Deschampsia caespitosa & $10.5 \pm 6.3$ & $6.5 \pm 1.3$ \\
\hline Euphorbia cyparissias & $41.7 \pm 15.4$ & $18.3 \pm 15.8$ \\
\hline Festuca ovina & $0.7 \pm 1.5$ & 0.0 \\
\hline Hieracium murorum & $79.2 \pm 22.6$ & $59.4 \pm 15.6$ \\
\hline Leontodon autumnalis & $16.6 \pm 8.4$ & $7.5 \pm 3.6$ \\
\hline Linaria vulgaris & $66.9 \pm 15.4$ & $47.9 \pm 10.0$ \\
\hline Linum catharticum & $1.5 \pm 3.2$ & $0.5 \pm 3.6$ \\
\hline Plantago lanceolata & $20.2 \pm 10.8$ & $11.8 \pm 1.8$ \\
\hline Populus tremula & $48.0 \pm 15.4$ & 0.0 \\
\hline Scrophularia nodosa & $19.2 \pm 10.4$ & $9.6 \pm 4.9$ \\
\hline Solidago gigantea & $43.5 \pm 7.2$ & $9.9 \pm 1.5$ \\
\hline Solidago virgaurea & $28.1 \pm 4.9$ & $12.7 \pm 7.2$ \\
\hline Sonchus arvensis & $67.3 \pm 8.9$ & $31.9 \pm 4.9$ \\
\hline Taraxacum officinale & $11.6 \pm 1.5$ & $2.3 \pm 0.2$ \\
\hline Tussilago farfara & $6.1 \pm 10.4$ & $2.8 \pm 6.3$ \\
\hline Viola tricolor & $8.7 \pm 2.7$ & $2.1 \pm 0.5$ \\
\hline \multicolumn{3}{|l|}{ Part 2} \\
\hline Campanula Irachelium & $0.7 \pm 1.3$ & 0.0 \\
\hline Cirsium anvense & $2.6 \pm 11.7$ & $0.5 \pm 7.7$ \\
\hline Cirsium vulgare & $64.1 \pm 12.4$ & $49.6 \pm 13.4$ \\
\hline Convolvulus arvensis & $5.5 \pm 2.5$ & $2.2 \pm 1.8$ \\
\hline Daucus carota & $0.7 \pm 5.0$ & $0.6 \pm 1.5$ \\
\hline Epilobium ángusifolium! & $30.6 \pm 6.3$ & $15.4 \pm 7.6$ \\
\hline Epilobium dodonaei & $82 \pm 5.4$ & $40.8 \pm 12.6$ \\
\hline Erigeron acer & $0.6 \pm 2.4$ & 0.0 \\
\hline Festuca ovina & $32.4 \pm 13.8$ & $20.1 \pm 16.0$ \\
\hline Hieracium lachenalii & $10.5 \pm 6.9$ & $2.8 \pm 5.1$ \\
\hline Holcus lanatus & $36.1 \pm 7.6$ & $23.2 \pm 18.4$ \\
\hline Leontodon hispidus & $9.7 \pm 6.4$ & $3.9 \pm 1.7$ \\
\hline Melandrium album & $2.6 \pm 5.3$ & $1.7 \pm 3.1$ \\
\hline Melilotus alba & $46.4 \pm 12.3$ & $11.6 \pm 7.6$ \\
\hline Myricaria gemanica & $9.3 \pm 18.1$ & $7.7 \pm 16.2$ \\
\hline Oenothera biennis & $43.6 \pm 16.8$ & $13.1 \pm 5.9$ \\
\hline Plantago lanceolata & $55 \pm 22.6$ & $42 \pm 8.4$ \\
\hline Populus tremula & $2.2 \pm 5.1$ & $1.6 \pm 2.6$ \\
\hline Scrophularia nodosa & $58.4 \pm 12.9$ & $44.8 \pm 7.2$ \\
\hline Solidago gigantea & $14.6 \pm 10.1$ & $3.7 \pm 9.4$ \\
\hline Taraxacum officinale & $17.1 \pm 9.8$ & $5.9 \pm 3.7$ \\
\hline Trifolium repens & $60.1 \pm 19.8$ & $44.2 \pm 14.6$ \\
\hline Tussilago farfara & $37.4 \pm 17.4$ & $19.4 \pm 8.9$ \\
\hline Verbascum densiflorum & $8.7 \pm 13.2$ & $2.1 \pm 2.6$ \\
\hline \multicolumn{3}{|l|}{ Part 3} \\
\hline Achillea millefolium & $34 \pm 4.2$ & $16.8 \pm 3.3$ \\
\hline Agrostis stolonifera & $31.3 \pm 4.5$ & $16.3 \pm 4.6$ \\
\hline Amhenatherum elatius & $34.8 \pm 5.4$ & $4.0 \pm 3.5$ \\
\hline Anthemisia vulgaris & $0.9 \pm 13.9$ & $0.1 \pm 6.1$ \\
\hline Chenopodium rubrum & $0.7 \pm 5.1$ & 0.0 \\
\hline Cirsium anense & $2.6 \pm 11.7$ & $0.5 \pm 7.7$ \\
\hline Cirsium v'ulgare & $10.7 \pm 7.1$ & $4.5 \pm 3.4$ \\
\hline Daucus carota & $0.6 \pm 5.3$ & 0.0 \\
\hline Festuca ovina & $2.6 \pm 4.4$ & $0.5 \pm 1.7$ \\
\hline Hieracium piloselloides & $10.9 \pm 4.2$ & $4.1 \pm 2.7$ \\
\hline Medicago lupulina & $62.0 \pm 18.7$ & $10.5 \pm 4.7$ \\
\hline Plantago lanceolata & $41 \pm 9.3$ & $8.4 \pm 5.0$ \\
\hline Populus tremula & $16.9 \pm 8.4$ & $4.1 \pm 5.6$ \\
\hline Reynoutria sachalinensis & $0.9 \pm 3.2$ & $0.1 \pm 1.8$ \\
\hline Solidago gigantea & $19.6 \pm 7.4$ & $13.5 \pm 3.7$ \\
\hline Taraxacum officinale & $7.7 \pm 4.2$ & $4.1 \pm 2.0$ \\
\hline Tripleurospermum inodorum & $21.8 \pm 6.3$ & $10.2 \pm 5.2$ \\
\hline Tussilago farfara & $7.9 \pm 3.4$ & 0.0 \\
\hline Verbascum densiflorum & $0.5 \pm 2.8$ & $0.3 \pm 3.7$ \\
\hline Vicia cracca & $29.8 \pm 11.2$ & $13.4 \pm 4.6$ \\
\hline Viola tricolor & $13.1 \pm 5.6$ & $4.9 \pm 2.8$ \\
\hline
\end{tabular}

plant species. However, only some of them grew in abundant populations e.g. Myricaria germanica (Table 3). Nonmycorrhizal plants (42\% of the number of species) such as Silene vulgaris, Calamagrostis epigeios, Rumex acetosa and Cardaminopsis arenosa were still very frequent in this part (Table 2). Roots of Plantago lanceolata, Scrophularia nodosa and Cirsium vulgare were heavily colonised, and also the arbuscule richness was high (Table 4). The arbuscule richness was lower than on the 20 years old stage and did not exceed $50 \%$ (Table 4). The number of species with low abundance of arbuscules was twice increased.

\section{0 years-old zinc wastes}

The vegetation of this stage differed from the previous ones in richness and ground cover (up to $85 \%$ ). It was dominated by abundant populations of Solidago gigantea, Plantago lanceolata, Arthemisia vulgaris, Achillea millefolium and Daucus carota forming big tufts and clusters (Table 3). Mycorrhizal species made up to $59 \%$ of the total number of plants, as in the case of the 30-40 years-old wastes. At the same time, however, these species dominated the vegetation. Arbuscules were noted in $55 \%$ of species, however, plants with low arbuscule richness (up to $10 \%$ ) dominated. The value of this parameter did not exceed 20\% (Table 4). Some nonmycorrhizal species, which were common in youngest stages did not appear in this part (e.g. Cardaminopsis arenosa) (Table 2).

\section{DISCUSSION}

Despite the large areas taken by industrial wastes in Central Europe the investigations on the mycorrhiza of plants colonising such places are comparatively rare. So far such data are available for Poland from wastes of electricity power plant (Turnau 1987) soda factory spoil mound (Pawłowska 1991), calamine wastes (Pawłowska et al. 1996; Turnau et al. 1996) and zinc wastes (Turnau 1998; Turnau et al. 2000). Although heavy metal containing wastes have already been included in many investigations the present paper is the first one to give the characteristic of the successional stages occurring during 50 years from the moment of the waste deposition. The estimation of the age was possible on the basis of the documentation of the area. Moreover, chemical characterisation of the substratum, carried out within this research provided additional information which could be important for the comparison of data and could allow for avoidance of wrong conclusions concerning the substrata which could have originated as a result of different technologies used. In the present research 69 plant species appearing on the zinc wastes were analysed. 47 were found to form arbuscular mycorrhiza including 15 that were facultative hosts for AM fungi. According to the available literature the mycorrhizal status of 7 species of vascular plants found in this area have been studied for the first time. No mycorrhizal colonisation has been found in the case of Carex spicata and Reynoutria japonica, while Myricaria germanica, Epilobium dodonaei, Hieracium piloselloides, Verbascum densiflorum, Solidago gigantea, evidently form arbuscular mycorrhizas, including the formation of fully developed arbuscules.

The zinc waste of Wełnowiec is an example of an area on which, due to high heavy metal content, the infertility of the substratum and the lack of the appropriate soil structure the spontaneous revegetation is a very long process. High heavy metal content seems to be the main problem on the youngest 
wastes (under 20 years old). This part of the waste was characterised by the highest content of extractable metals such as $\mathrm{Zn}$, $\mathrm{Pb}$ and $\mathrm{Cd}$. This was correlated with the lack of arbuscules within Tussillago farfara roots, which in the later stages of succession developed arbuscular mycorrhiza. The mycelium forming coils and vesicles was the only sign of AMF presence in the youngest stage of waste revegetation. The following two successional stages were characterised by much more abundant arbuscule formation while at the last stage this parameter was strongly decreased. This might be caused by the much higher availability of $\mathrm{Cu}$ in these wastes; however, other reasons could not be excluded.

The above described plant succession on heavy metal containing wastes generally followed the classical model proposed by Janos (1980) for disturbed habitats with the early dominance of nonmycorrhizal plants, later replaced with facultative and finally obligatory mycorrhizal species. In the case of the Wetnowiec wastes the first stage was dominated by nonmycorrhizal plants which are mostly known as heavy metal accumulating plants. Silene vulgaris, Cardaminopsis arenosa and Agrostis capillaris are typical examples of this plant group. In addition, this stage was much longer than in the so far published cases (Allen and Allen 1980) what was probably due to especially severe conditions resulting in the delay of AM fungi establishment. The role of AM fungi in revegetation of mine wastes is comparatively well known (Daft and Hacskaylo 1976; Daft and Nickolson 1974; Allen 1989a, b; Miller and Jastrow 1992; Allen and Allen 1990), however, so far no restoration practices involving this group of fungi were carried out in Poland. Basing on experiences obtained in other regions the rate of restoration may be increased by the manipulation of the mycorrhizal fungal population or the inoculation techniques (Reeves et al. 1979; Janos 1980). The usefulness of indigenous AMF used as inoculants to reclaim mine spoils (Khan 1981; Stahl et al. 1988) and oil polluted soil (Call and McKell 1982; Cabello $1995,1997,1999)$ has been shown by several authors. The number of AMF propagules depends on factors such as soil nutritional status, host plant, AMF propagule density, effectiveness of AMF species and competition between them and other soil microorganisms (Cabello 1999). Fungi isolated from polluted areas were more effective than those originating from unpolluted sites, suggesting the adaptation of fungi to persistent toxicants in soil. The AM fungi from the Wełnowiec waste could be used in future for production of inoculum well adapted for edaphic and climatic conditions and by this better adapted for restoration practices in the particular area. Before the introduction of the inoculum in the first successional stages it seems to be necessary to use appropriate techniques lowering the toxicity of the substratum and increasing the nutritional status. Optimalisation of both should be carried out on the basis of experiments where the AM fungal activity would be monitored using the spore germination test as described by Weissenhorn et al. (1993) or by checking mycorrhiza development of selected plants. In the part of the waste which is already colonised by mycorrhizal fungi the restoration techniques should enhance mycorrhiza development, for example by applying appropriate levels and kinds of organic amendments which again should be optimalised by experimental trials. Another aim of phytoremediation of the waste is the selection of appropriate plant species. The so far developed techniques often involve nonmycorrhizal plant species. The growth of plants such as Silene vulgaris and Thlaspi caerulescens had, however, a more negative effect on the number of AM spores in the substratum than while mycorrhizal Zea mays was present (Pawłowska et al. 2000). In the case of the Wetnowiec wastes the native plant species could be selected on the basis of above presented data concerning their mycorrhizal status.

\section{ACKNOWLEDGMENTS}

Special thanks are due to Dr Ryszard Ciepał (Department of Ecology, Silesian University, Katowice) and Dr Barbara Godzik (Polish Academy of Sciences, Kraków) for the help in estimation of heavy metal levels and it availability, to eng. Maciej Terakowski (Institute for Ecology of Industrial Areas, Katowice) for the help in soil analysis and to Dr Anna Jurkiewicz for her linguistic comments during the preparation of the manuscript.

The research was supported by the Committee for Scientific Research in Poland, grant no. PB 0281/PO4/95/08.

\section{LITERATURE CITED}

ALLEN E.B. 1989a. The restoration of disturbed arid landscapes with special reference to mycorrhizal fungi. J. Arid Environm. 17: 279-286.

ALLEN M.F. 1989b. Mycorrhizae and rehabilitation of disturbed arid soils: Processes and practices. Arid Soil Res. 3: 229-241.

ALLEN E.B., ALLEN M.F. 1980. Natural re-establishment of vesicular-arbuscular mycorrhizae following stripmine reclamation in Wyoming. J. Appl. Ecol. 17: 139-147.

ALLEN E.B., ALLEN M.F. 1990. The mediation of competition by mycorrhizal fungi in successional and patchy environments. In: Grace J.R., Tilman G.D. (eds) Perspectives in plant competition. Academic Press, New York, pp. 367-389.

BRAUN-BLANQUET J. 1964. Pflanzensozologie, Grundzüge der Vegetationskunde. 3 Aufl. Springer Verl., Wien-New York.

CABELLO M.N. 1995. Effect of hydrocarbon pollution on vesiculararbuscular mycorrhizal fungi (VAM) Bol. Micol. (Chile) 10: 77-83.

CABELLO M.N. 1997. Hydrocarbon pollution: its effect on native arbuscular mycorrhizal fungi (AMF). FEMS Microbiol. Ecol. 22: 233-236.

CABELLO M.N. 1999. Effectiveness of indigenous arbuscular mycorrhizal fungi (AMF) isolated from hydrocarbon polluted soils. J. Basic Microbiol. 39(2): 89-95.

CALL C.A., MCKELL C.M. 1982. Vesicular-arbuscular mycorrhizae - a natural revegetation strategy for disposed processed oil shale. Reclam. Revegn. Res. 1: 337-347.

DAFT M.J., HACSKAYLO E. 1976. Arbuscular mycorrhizas in anthracite and bituminous coal wastes of Pennsylvania. J. Appl. Ecol. 13: 523-531.

DAFT M.J., NICKOLSON T.H. 1974. Arbuscular mycorrhizas in plants colonizing coal wastes in Scotland. New Phytol. 73: 1129$-1137$.

FALIŃSKI J.B. 1972. Synantropizacja szaty roślinnej - próba określenia istoty procesu i głównych kierunków badań. Phytocenosis 1(3): 157-169.

HASELWANDTER K. 1997. Soil micro-organisms, mycorrhiza, and restoration ecology. In: Urbańska K., Webb N.R., Edwards P.J. (eds) Restoration ecology and sustainable development. Cambridge Univ. Press, Cambridge, pp. 65-80.

JANOS D.P. 1980. Mycorrhizae influence tropical succession. Biotropica 12: 56-64.

KHAN A.G. 1981. Growth responses of endomycorrhizal onions in unsterilized coal wasts. New Phytol. 87: 363-370.

LOVERA M., CUENCA G. 1996. Arbuscular mycorrhizal infection in Cyperaceae and Gramineae from natural, disturbed and restored savannas in La Gran Sabana, Venezuela. Mycorrhiza 6: 111-118. 
LITYŃSKI T., JURKOWSKA H. 1982. Żyzność gleby a odżywianie się roślin. PWN, Warszawa.

MILLER R.M., JASTROW J.D. 1992. The application of VA mycorrhizae to ecosystem restoration and reclamation. In: Allen M.F. (ed.) Mycorrhizal functioning: an integrative plant-fungal process. Chapman and Hall, New York, pp. 438-467.

OSTROWSKA A., GAWLIŃSKI S., SZCZUBIAŁKA P. 1991. Metody analizy i oceny właściwości gleb i roślin. Katalog. Instytut Ochrony Środowiska, Warszawa.

PATRZALEK A., ROSTAŃSKI A. 1992. Procesy glebotwórcze i zmiany roślinności na skarpie rekultywowanego biologicznie zwałowiska odpadów po kopalnictwie węgla kamiennego. Arch. Ochr. Środ. 3-4: 157-168.

PAWŁOWSKA T. 1991. Plant mycorrhizae in the sedimentation tanks of the Cracow Soda Factory. Zesz. Nauk. Uniw. Jagiellon., Prace Bot. 22: 163-170.

PAWŁOWSKA T.E., CHANEY R.L., CHIN L., CHARVAT I. 2000. Effects of metal phytoextraction practices on the indigenous community of arbuscular mycorrhizal fungi at a metal-contaminated landfill. Appl. Environm. Microbiol. 66 (6): 2526-2530.

PAWŁOWSKA T.E., BŁASZKOWSKI J., RÜHLING A. 1996. The mycorrhizal status of plants colonizing a calamine spoil mound in southern Poland. Mycorrhiza 6: 499-505.

PHILLIPS J.M., HAYMAN D.S. 1970. Improved procedures for clearing roots and staining parasitic and vesicular-arbuscular mycorrhizal fungi for rapid assesment of infection. Trans. Brit. Mycol. Soc. 55: 158-160.

REEVES F.B., WAGNER D.W., MOORMAN T., KIEL J. 1979. The role of endomycorrhizae in revegetation practises in the semi-arid west. I. A comparison of incidence of mycorrhizae in severly disturbed vs. natural environments. Am. J. Bot. 66: 1-13.

ROSTAŃSKI A. 1991. Spontaniczna sukcesja roślinności na wybranych zwałach poprzemysłowych w województwie katowickim. Kształtowanie środowiska geograficznego i ochrona przyrody na obszarach uprzemysłowionych 3: 35-38.

ROSTAŃSKI A. 1997a. Flora spontaniczna hałd Górnego Śląska. Arch. Ochr. Środ. 23 (3-4): 159-165.

ROSTAŃSKI A. 1997b. Zawartość metali ciężkich w glebie i roślinach z otoczenia niektórych emitorów zanieczyszczeń na Górnym Śląsku. Arch. Ochr. Środ. 23 (3-4): 181-189.

ROSTAŃSKI K. 1990. Skutki antropopresji we florze naczyniowej regionu uprzemysłowionego na przykładzie Górnośląskiego Okręgu
Przemysłowego i terenów sąsiednich. In: Godzik S. (ed) Zagrożenie i stan środowiska przyrodniczego rejonu śląsko-dąbrowskiego 62: 58-69.

ROTHMALER W. 1994. Excursionsflora von Deutschland. 4. Gefässpflanzen: Kritischer Band. G. Fischer Verl., Jena, Stuttgart.

STAHL P.D., WILLIAMS S.E., CHRISTENSEN M. 1988.Efficacy of native vesicular-arbuscular mycorrhizal fungi after severe soil disturbance. New Phytol. 110: 347-354

TOKARSKA-GUZIK B., ROSTAŃSKI A., KLOTZ S. 1991. Roślinność hałdy pocynkowej w Katowicach-Wełnowcu. Acta Biol. Siles. 19(36): 94-102.

TROUVELOT A., KOUGH J.L., GIANINAZZI-PEARSON V. 1986. Mesure du taux de mycorhization VA d'un systéme radiculaire. Recherche de méthodes d'estimationayant une signification fonctionelle. Mycorrhizae: physiology and genetics. ESM 1: 217-221.

TURNAU K. 1987. Changes in mycoflora during revegetation of flyash heap at Skawina (southern Poland). Zesz. Nauk. Uniw. Jagiellon., Prace Bot. 15: 159-163.

TURNAU K. 1998. Heavy metal uptake and arbuscular mycorrhiza development of Euphorbia cyparissias on zinc wastes in South Poland. Acta Soc. Bot. Pol. 67: 105-113.

TURNAU K. KOTTKE I. DEXHEIMER J. 1996. Toxic element filtering in Rhizopogon roseolus/Pinus sylvestris mycorrhizas collected from calamine dumps. Mycol. Res. 100 (1): 16-22.

TURNAU K., RYSZKA P., VAN TUINEN D., GIANINAZZI-PEARSON V. 2000. Identification of arbuscular mycorrhizal fungi in soils and roots of plants colonizing zinc wastes in Southern Poland. Mycorrhiza. (in press)

WEISSENHORN I., LEYVAL C., BERHELIN J. 1993. Cd-tolerant arbuscular mycorrhizal (AM) fungi from heavy metal polluted soil. Plant \& Soil 157: 247-256.

WEISSENHORN I., MENCH M., LEYVAL C. 1995. Bioavibility of heavy metals and abundance of arbuscular mycorrhiza in a sewage sludge amended sandy soil. Soil Biol. Biochem. 27: 287-296.

WIKA S., SENDEK A. 1993. Sukcesja swoistej roślinności na hałdzie hutniczej w Siemianowicach Śląskich. Kształtowanie środowiska geograficznego i ochrona przyrody na obszarach uprzemysłowionych i zurbanizowanych 9: 23-30.

WOJCIEROWSKA M. 1968. Projekt wstępny Nr 97-544 rekultywacji i zagospodarowania terenów zwałowisk (M.S.). Katowice, Huta „Silesia”,

\section{MIKORYZA ARBUSKULARNA I SUKCESJA ROŚLINNA NA HAŁDZIE POCYNKOWEJ W KATOWICACH-WEŁNOWCU}

\section{STRESZCZENIE}

Zbadano status mikoryzowy roślin hałdy pocynkowej w Katowicach-Wełnowcu. Odnotowano 69 gatunków (z 25 rodzin). Ponad $60 \%$ z nich tworzyło mikoryzę. Gatunki niemikoryzowe, jak Cardaminopsis arenosa i Silenene inflata, dominowały na młodszych częściach hałdy. Tussilago farfara był tam jedynym gatunkiem mikoryzowym, jednak nie stwierdzono u niego arbuskul. Liczba gatunków mikoryzowych wzrosła na starszych częściach. Rośliny mikoryzowe stanowiły tam około $60 \%$ wszystkich gatunków. Częstość występowania gatunków mikoryzowych była najwyższa na najstarszej części hałdy. Przedyskutowano możliwość wykorzystania otrzymanych wyników w rekultywacji tego typu terenów.

SŁOWA KLUCZOWE: mikoryza arbuskularna, hałdy przemysłowe, metale ciężkie. 